\title{
Exploited for a Good Cause? Campaigning Against Unpaid Internships in the UK Charity Sector
}

\author{
Vera Weghman \\ University of Nottingham, Nottingham, UK, Idxvw@nottingham.ac.uk
}

\begin{abstract}
In this activist report I aim to show that unpaid internships in charities need to be understood as both morally unjust and exploitative, and that we can do something about it. Together with my fellow interns and interns from another charity, I organized a campaign, NoPay?NoWay!, for a decent wage for all workers in the charity sector, including interns. After six months, we successfully managed to stop the use of unpaid internships in both workplaces. This is my story.
\end{abstract}

Keywords: internships, volunteering, unpaid work, placements, work-experiences, no-wage economy, charities, exploitation, protest, campaigning, employability, labour of love, United Kingdom

\begin{abstract}
Acknowledgement: I would like to thank Nicole Cohen and Greig de Peuter for very helpful comments on earlier versions of this report. I also would like to give special thanks to the Precarious Workers Brigade, as their encouragement made the NoPay?NoWay! campaign possible.
\end{abstract}

Seventy percent of people aged 16 to 76 in England believe that unpaid internships are unfair because only the wealthy are able to work unpaid (The Sutton Trust 2014). But what if this unpaid work takes place in a non-profit organization that is dedicated to a good cause, such as reducing poverty and inequality?

One might argue that internships in a charity are a win-win situation. The charity needs volunteers and the interns enhance their job prospects. From Stephen Resnick and Richard Wolff's (1989) postmodern Marxist viewpoint, non-profit organizations cannot, by definition, exploit workers, as surplus value is neither appropriated nor subsumed by the employer. Contrary to both standpoints, I aim to show that unpaid internships in charities need to be understood as both morally unjust and exploitative, and that we can do something about it. I learned this while an intern at a charity where, with my fellow interns and interns from another charity, I organized a campaign, NoPay?NoWay!, for a decent wage for all workers in the charity sector, including interns. After six months, we successfully managed to stop the use of unpaid internships in both workplaces. This is my story.

\section{Interning at a Charity}

Struggling to find a job after graduating, I took on an unpaid internship in a charity in London (which I refer to as "the charity"), hoping the position would lead to paid employment. It soon became clear to me that securing paid employment through an internship was highly unlikely. Like in many charities, almost all positions at the charity required at least five years paid work experience elsewhere. Yet paid entry-level jobs used to be a part of the charity's organizational structure. Shockingly, the charity's old entry-level job descriptions (which were leaked to me) were identical with the descriptions of its new voluntary internships. Cutting costs by replacing paid staff with unpaid interns is a common phenomenon among charities. In fact, it is even advised by the Charity Commission $(2009,3)$, which suggests that charities deal with funding difficulties by using volunteers "efficiently." The replacement of entry-level positions with internships shows that internships are in fact contributing to unemployment and job insecurity rather than decreasing it.

However, while the economic recession has burdened charities with less funding and more work, it is not the case that the charity lacked sufficient funds to pay all of its staff members, including interns. Rather, the charity's internal wage distribution had changed 
dramatically over the years. Initially, the charity had a flat pay scale under which everyone was paid the same. Now it has a hierarchical pay structure, with an executive director earning $£ 59,000$ per annum, department directors $£ 43,000$ per annum, senior officers $£ 34,000$ per annum, and officers $£ 32,000$ per annum (figures 2012 until March 2013). Clearly, senior officials saw generous increases in their own pay as more important than providing paid, entry-level positions. To take advantage of the "reserve army" of labour (Marx 1995) readily available through the false promise of employability while simultaneously paying certain employees generously must be understood as exploitation. This is principally because the labour power of unpaid interns is appropriated by other workers.

In the U.K., the replacement of (entry-level) jobs with internships is facilitated by a legal loophole. According to the National Minimum Wage Act 1998, every worker over the age of 21 is entitled to a minimum of $£ 6.50$ per hour. Unpaid internships are therefore illegal. However, section 44 of the Act provides an exemption for "voluntary workers." A voluntary worker undertakes work for a charity, voluntary organization, associated fundraising body or a statutory body and is therefore not entitled to monetary payments other than expenses. This exemption, which aimed to encourage volunteering, legalizes unpaid internships in the charity sector. Yet there is a profound difference between volunteering and an internship: the hours and tasks of an internship are fixed; a volunteer, however, must not be placed under any obligation to perform any activities as instructed by the employer. As such, a volunteer is also able to come and go as they please.

Nonetheless, the terms volunteering and interning are often used interchangeably. The first step of our campaign was thus to distinguish between the two terms. By drawing on the work of the Precarious Workers Brigade, which put together a well-researched guide called Surviving Internships: A Counter Guide to Free Labour in the Arts (Carrotworkers' Collective 2009), ${ }^{1}$ we argued that the motive is the deciding criteria for differentiating volunteering from internships: the motive to undertake an internship is first and foremost to advance one's career, whereas volunteering is without career intention and primarily about freely donating one's time to a cause they particularly identify with. In addition, we argued that volunteering is morally unjust if used to cut staff or to boost wages for the other workers in the organization. In other words, volunteering is morally good, if a) all people in the organization work unpaid, such as in small community-run organizations or activist groups, or b) there is an equal distribution of the limited funds, which is facilitated by a democratic decision-making process in which some people might disclaim their financial remuneration as they have secured incomes by other means. Overall, our aim was not to campaign against volunteering per se, but against the replacement of (entry-level) workers with volunteers/voluntary interns.

\section{The Campaign}

Angered by the injustice of our position and inspired by the book Intern Nation (Perlin 2012), my fellow interns and I decided to enter pay negotiations. Our first attempt failed terribly: our director told us that to "hire us" would result in the need to fire someone else. To no one's surprise, our arguments for internal wage distribution went unheard. At this point we had no plan to move forward. We were scared of the possible repercussions of taking industrial action, as we were hesitant to bite the hand that "feeds" us. After all, we were working for a reference and a network, so provoking the executive director of the charity was not in our best interests.

To increase our bargaining power we decided to unite with other interns. Yet interns constitute an invisible workforce, are hard to track down, and often only work for a short time in any given charity. Despite writing to over 100 charities asking for their interns' contact details under the guise of social networking, only two charities forwarded their interns' contacts. Through word of mouth and Facebook we managed to arrange a meeting with 30 interns, many of whom were in their third, fourth, or even seventh unpaid internship. Most of the in-

\footnotetext{
${ }^{1}$ Carrotworkers' Collective is the organizational predecessor to the Precarious Workers Brigade.
} 
terns attending this meeting felt that their vulnerable position in the labour market was exploited and were very angry about it.

However, almost all were faced with the moral dilemma that they also loved the charities they worked for and did not want to harm the charities' images. Protesting outside the charities or turning to the media were not feasible campaigning strategies for many of us. We debated whether we should launch a less militant campaign, and if so, what the right strategy would be. These questions divided the group. Many feared ruining one's career through campaigning and only a few were ready to take action. In the discussion it also became clear that about half of the interns came from for-profit art galleries. As such, they had the option of participating in the "claim back your pay" campaign run by the small NGO Intern Aware. This campaign helps interns who worked for for-profit companies to claim back their unlawfully deducted minimum wage.

That first meeting was a big disappointment. We had hoped that more interns in charities would take the step from complaining to campaigning. However, we had at least managed to join forces with the interns of another charity, which was similar to ours. In fact, the charities were competitors and watched each other's practices. We started to run parallel campaigns and soon realized that our strength came from our unity.

Internally, as both charities were unionized, we coordinated with the trade union representatives at both charities, who were very supportive of our campaign. On their advice we compromised to make our success more likely. We decided to focus on paid internships and left the issue of entry-level positions to another struggle. In the end we did not have much time. It was already mid-summer, which meant that the main campaigner from the other charity and I had only two more months of our internships left. In this short time, we had frequent meetings with the trade union representatives. They helped us draft letters to the directors, which set out our demands and tried to persuade them that paying their interns would improve the charities' images. This turned out to be unsuccessful. Next, we wrote to the trustees. In one charity we managed to get our issue on the agenda of their next meeting. In the other charity an extra meeting took place to debate the "intern question" with the director, trade union representatives, and trustees.

Charity staff were generally encouraging. We thought that working in a charity while campaigning against its practice of unpaid internships would turn our working life into a nightmare. Instead, we gained a lot of respect. However, it was interesting that those few people who were opposed to our campaign were those who should understand our position the best: a member of staff who undertook a paid internship in the charity a few years before and other interns who chose not to take part in the campaign. This division was frustrating and at times made us feel alone in our campaign.

Externally, we were advised and encouraged by the Precarious Workers Brigade. We felt strong because we knew that if we would choose to organize a protest we had the great support network of the Precarious Workers Brigade to back us up. We launched a group called NoPay?NoWay! and set up a blog and a Facebook page for wider outreach. Through irregular meetings, other interns joined us. In these meetings we debated our strategies. Should we emulate groups such as Boycott Workfare that have successfully named and shamed companies and charities through protests and social media? We were still hesitant to protest outside our charities. However, soon a crucial event came up, which we knew most of the directors of the charities we interned for would attend. We decided to do a leaflet action. In a group of ten, we gathered outside the building and approached the attendees of the event urging them to pay their interns. The responses were mixed: some people were sympathetic and argued that they would like to pay their interns but simply cannot afford to, and others were rather hostile. Our next idea was to use Twitter to bring the issue of unpaid internships in charities to the public and, most importantly, to the attention of the charities' supporters. When some tweets appeared on the charity Twitter feed, we quickly realized that we hit a nerve with the directors, who tweeted back in a panic. Not long after that Twitter exchange, I actually saw the book Intern Nation lying on the director's desk. This was when I 
knew we would get somewhere. We had reached the point where our director could no longer ignore us.

Our campaign was partially successful: we managed to stop unpaid internships in both organizations. One charity stopped internships entirely. The other one introduced paid internships but still continued to rely on a lot of flexible volunteering work. Stopping unpaid internships was a great step in the right direction, but to achieve intergenerational and inclusive justice, entry-level positions need to become a part of every organization, may they be for-profit or non-profit. The surest way to make this possible is by re-distributing wages, and charities should lead with a good example. In retrospect, I believe we should have struck while the iron was hot and demanded entry-level positions through loud and lively protests. Still, it is an important step that interns at these charities are no longer exploited for a good cause, and I hope our campaign might inspire other interns to step up for justice. Fellow interns, we have nothing to lose but a reference. We have a wage to win!

\section{References}

Carrotworkers' Collective. 2009. Surviving Internships. A Counter Guide to Free Labour in the Arts. Accessed February 13, 2015. https://carrotworkers.wordpress.com/counter-internship-guide/.

Charity Commission. 2009. Regional focus group discussions: A summary. How can the Charity Commission support charities through the recession. Accessed February 13, 2015. http://webarchive.nationalarchives.gov.uk/20140505102719/.

Perlin, Ross. 2012. Intern Nation: How to Earn Nothing and Learn Little in the Brave New Economy. London: Verso.

Precarious Workers Brigade. n.d.. Accessed February 13, 2015. http://precariousworkersbrigade.tumblr.com.

Marx, Karl. 1995. Capital: An Abridged Edition. Oxford: Oxford University Press.

Resnick, Stephen A. and Richard D. Wolff. 1989. Knowledge and Class. A Marxian Critique of Political Economy. Chicago: The University of Chicago Press.

The Sutton Trust. 2014. Research Brief. Internship or Indenture? Accessed February 13, 2015. http://www.suttontrust.com/wp-content/uploads/2014/11/Unpaid-Internships.pdf.

\section{About the Author}

Vera Weghman

Vera Weghman is currently doing her $\mathrm{PhD}$ at the University of Nottingham. Her thesis is entitled The Employability Promise: The Cases of Unpaid Internships and Workfare in the UK and is funded by the Rosa Luxemburg Foundation. She has also been an activist in various groups and movements and recently co-founded the grassroots trade union, United Voices of the World, which is almost entirely comprised of migrant workers in London's low wage, service sector. 